\title{
O ópio do povo? O futebol e as manifestações políticas no Brasil entre 2013 e 2020
}

\section{The opium of the people? Football and political protest in Brazil between 2013 and 2020}

\section{¿El opio del pueblo? Fútbol y manifestaciones políticas en Brasil entre 2013 y 2020}

\author{
iD 9 Eric Monné Fraga de Oliveira \\ Universidade Federal Fluminense, Niterói, Rio de Janeiro, Brasil \\ ericmfo@hotmail.com
}

Resumo: O presente artigo tem como objetivo participar da discussão acerca das multifacetadas relações entre futebol e manifestações políticas no Brasil. Constatamos que existem três interpretações correntes a respeito dessas relações no debate público, nas quais: 1) o futebol distancia os sujeitos da busca por seus interesses políticos; 2) futebol e política deveriam ser duas esferas totalmente separadas da vida social; 3) a experiência como torcedores de futebol é uma má influência para os cidadãos em seus comportamentos políticos. Para argumentar contra essas interpretações, observamos três momentos de manifestações políticas entre 2013 e 2020 que se relacionam de maneiras distintas com o futebol: os atos públicos contra a Copa do Mundo de 2014 da FIFA; as manifestações antipetistas e bolsonaristas; os protestos de torcedores contra Bolsonaro em meio à pandemia de COVID-19. Concluímos que o contexto do futebol pode oferecer múltiplas formas de cidadania e politização frequentemente insuficientes em outros espaços da vida social do país.

Palavras-chave: Futebol. Manifestações no Brasil. Política. Torcedores de futebol. Sociologia do esporte. 
Abstract: This article aims to participate in the discussion about the multifaceted relations between football and political protests in Brazil. We found that there are three current interpretations regarding these relations in the public debate, in which: 1) football distances subjects from their pursue of their political interests; 2 ) football and politics should be two completely separate spheres of social life; and 3) the experience as football supporters is a bad influence for citizens in their political behaviour. In order to argue against these interpretations, we observed three moments of political demonstrations between 2013 and 2020 that are related to football in different ways: the collective riots against the 2014 FIFA World Cup, the anti-PT and pro-Bolsonaro demonstrations and the football supporters' protests against Bolsonaro in the midst of the COVID-19 pandemic. We conclude that the context of football can offer multiple forms of citizenship and politicization that are often insufficient in other areas of the country's social life.

Keywords: Football. Protests in Brazil. Politics. Football supporters. Sociology of sport.

Resumen: Este artículo tiene como objetivo participar en la discusión sobre las relaciones multifacéticas entre el fútbol y las manifestaciones políticas en Brasil. Verificamos que existen tres interpretaciones actuales sobre estas relaciones en el debate público, en las que: 1) el fútbol aleja a los sujetos de la búsqueda de sus intereses políticos; 2) el fútbol y la política deberían ser dos esferas de la vida social completamente separadas; y 3) la experiencia como aficionados al fútbol es una mala influencia para los ciudadanos en su comportamiento político. Para argumentar en contra de estas interpretaciones, observamos tres momentos de manifestaciones políticas entre 2013 y 2020 que se relacionan de diferentes formas con el fútbol: los actos públicos contra la Copa Mundial de la FIFA 2014, las manifestaciones en contra del PT y en favor de Jair Bolsonaro y las protestas de aficionados al fútbol en contra de Bolsonaro en medio de la pandemia de COVID-19. Concluimos que el contexto del fútbol puede ofrecer múltiples formas de ciudadanía 
y politización a menudo insuficientes en otros ámbitos de la vida social del país.

Palabras clave: Fútbol. Manifestaciones en Brasil. Política. Aficionados al fútbol. Sociología del deporte.

Data de recebimento: 28/09/2020

Data de aprovação: 10/02/2021

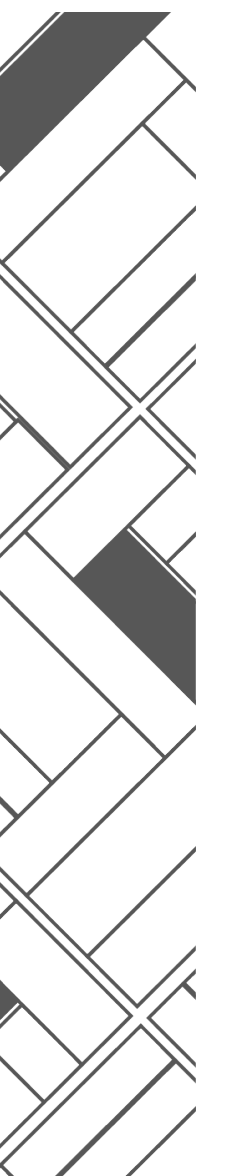




\section{Introdução}

Em Sport Matters (1999), Eric Dunning constatou que existe uma negligência do esporte na Sociologia. Segundo Dunning, essa negligência seria parcialmente oriunda de uma interpretação literal da décima primeira tese de Karl Marx sobre Feuerbach a respeito da necessidade de os filósofos participarem da transformação do mundo, de forma que se levaria a opor "interpretar" e "transformar" o mundo como duas atitudes antitéticas (p. 8) - algo contrário ao próprio pensamento marxista. A preocupação - em geral louvável - de sociólogos e cientistas sociais, marxistas ou não, em lidar com problemas no aqui e agora seria responsável por um interesse insuficiente em temas sociológicos considerados comparativamente banais, entre eles o esporte: "a dominant orientation towards the immediate solution of 'problems' was almost bound to have as a consequence a neglect of areas of social life such as sport" (p. 10).

Ao menos no Brasil essa tendência esteve acompanhada de uma visão compartilhada por muitas pessoas pertencentes às camadas com maior escolaridade, incluindo intelectuais e acadêmicos das ciências sociais, na qual o futebol por vezes é tomado como um elemento que alienaria o povo (a partir de uma interpretação do marxismo) ou embruteceria os indivíduos (na perspectiva liberal), distanciando-os do reconhecimento de seus "verdadeiros" interesses. A célebre frase de Marx (2005) sobre a religião é frequentemente adaptada - dentro e fora da academia - para se referir ao esporte mais popular do país como "o ópio do povo". Segundo o historiador Denaldo Alchorne de Souza (2018), a representação do futebol como algo alienante data da ditadura civil-militar, quando as vitórias da seleção nas Copas do Mundo da FIFA eram interpretadas por intelectuais de esquerda e movimentos sociais como favoráveis ao regime autoritário e empecilhos à redemocratização.

O passado elitista e excludente que acompanhou a chegada e as primeiras décadas do esporte no país, quando era praticado por homens brancos pertencentes às classes dominantes e 
O ópio do povo? O futebol e as manifestações políticas no Brasil entre 2013 e 2020 Eric Monné Fraga de Oliveira

que o consideravam como uma atividade distintiva (MELO, 2012; MALAIA, 2012), o histórico das relações entre a CBF e a ditadura civil-militar que afligiu o país entre 1964 e 1985 - especialmente em torno da Copa do Mundo de 1970, quando o Brasil se tornou o primeiro tricampeão do mundo na categoria masculina e adulta do esporte, em um processo que contou com participação massiva do governo desde a preparação para a competição (GUEDES; DA SILVA, 2019, p. 79) - e a transformação dos melhores jogadores em superastros globais multimilionários desde os anos 1990 - e, portanto, cada vez mais "distanciados" de suas origens socioeconômicas e geográficas, certamente favorecem o argumento contrário à capacidade desse esporte possibilitar situações e espaços para reflexões sobre a realidade social.

Em anos mais recentes, alguns jornalistas e outras figuras públicas têm mobilizado um princípio diverso para observar a relação entre futebol e política: eles admitem a existência dessa relação, mas defendem que ela deveria ser rompida em defesa de uma suposta "pureza" primordial do esporte ${ }^{1}$. A política seria, então, um elemento "sujo", capaz de "poluir" ou "manchar" (DOUGLAS, 1991) os valores desportivos, de outra forma límpidos. Nessa interpretação, o esporte deveria ser um momento de lazer liberto das preocupações com a realidade e os problemas que nela existem. A possibilidade alienadora do futebol, outrora criticada, passa a ser, de certa forma, exaltada: o futebol não deve oferecer aos sujeitos formas de interpretar a realidade que habitam.

Existe ainda uma terceira concepção negativa sobre a relação entre futebol e política no debate público. Nela, a rivalidade nem sempre saudável entre torcedores de futebol teria se tornado um modelo a partir do qual os cidadãos passariam a lidar com outras divergências, sobretudo na esfera política. Em setembro de 2013, a revista Carta Capital publicou um artigo de opinião que afirmava que "o Brasil precisa acabar com o fla-flu político"2 (32XSP, 2013),

\footnotetext{
$\overline{1 \text { Ver, por exemplo, o }}$ texto de Tiago Leifert, que defende que a combinação entre esporte e política seria prejudicial, particularmente no trecho: "Tem muita coisa contaminada por aí. Precisamos imunizar o pouco espaço que ainda temos de diversão" (LEIFERT, 2018).

2 "Fla-flu” é o nome dado ao clássico do futebol carioca entre o Clube de Regatas do Flamengo e o Fluminense Football Club.
} 
argumentando que essa atitude não é pertinente a regimes democráticos. Embora a democracia seja o regime político definido pelo dissenso, é preciso haver também espaço para a produção de consensos, enquanto que a metáfora do fla-flu, frequentemente utilizada durante a última década para se referir à polarização política no país, sugere que os torcedores de futebol são incapazes de alcançar consensos em discussões saudáveis - ao menos quando são envolvidos seus times de coração -, algo que seria reforçado pelas representações correntes sobre as torcidas organizadas como agrupamentos violentos.

Contudo, ao longo das últimas décadas, tem se proliferado o debate acadêmico sobre o futebol como um espaço social tanto sociologicamente relevante quanto atravessado por formas diversas de politização dos torcedores. O intuito do presente artigo é contribuir para esse debate, refletindo sobre algumas das principais formas pelas quais futebol e política se relacionaram nas manifestações políticas em território brasileiro entre 2013 e 2020. Esse período foi escolhido por ser marcado tanto por instabilidade e profundas transformações políticas e econômicas quanto pela realização de megaeventos esportivos no Brasil: a Copa das Confederações (2013) e a Copa do Mundo de futebol masculino da FIFA (2014), os Jogos Olímpicos e Parolímpicos (2016) e a Copa América de futebol masculino da CONMEBOL (2019). Durante esse período, o país presenciou atos públicos críticos à realização dos eventos FIFA (2013-2014), manifestações com grandes contingentes de pessoas portando trajes verde-amarelos e emulando a estética torcedora em favor de pautas associadas à direita e à extrema-direita do espectro político, e protestos de torcedores de futebol contra o presidente Jair Bolsonaro em meio à pandemia de COVID-19. Analisaremos a seguir esses três casos distintos, pois eles constituem exemplos da multiplicidade das formas pelas quais futebol e manifestações políticas podem estar associados.

Para a realização da pesquisa, partimos da literatura acadêmica específica sobre o tema para analisar o corpus constituído por reportagens dos seguintes jornais online: G1, Globo Esporte, 
O ópio do povo? O futebol e as manifestações políticas no Brasil entre 2013 e 2020 Eric Monné Fraga de Oliveira

Carta Capital, Estadão (O Estado de São Paulo), UOL, Folha de São Paulo, BBC e El País. Foram escolhidos para acompanhamento os jornais de grandes corporações midiáticas por dois motivos principais: 1) o escopo de suas atividades permite a produção de um grande volume de reportagens, contemplando os acontecimentos e assuntos aqui abordados; 2) facilidade e praticidade no uso da ferramenta de pesquisa dos sites. Cabe observar que reconhecemos a pouca variedade do corte ideológico representado por essa triagem. Por um lado, rejeitamos a percepção segundo a qual o jornalismo seria um parâmetro completa ou satisfatoriamente fidedigno, objetivo ou neutro de registro e compreensão da realidade, compreendendo que as notícias são tanto o "resultado de disputas em torno de um amplo conjunto de interesses sociais" (FERNANDES; TEIXEIRA, 2018, p. 917) quanto elementos que participam nas disputas pela produção e interpretação da própria realidade social a que se referem ${ }^{3}$. Por outro lado, tratamos o corpus de forma a limitar a influência do conteúdo ideológico dos jornais na presente pesquisa ao cruzar as informações entre as notícias selecionadas com as informações e interpretações presentes na literatura específica sobre os temas abordados, possibilitando assim uma postura crítica. Os critérios e efeitos ideológicos envolvidos na seleção, hierarquização e confecção, isto é, na construção social das notícias sobre torcedores de futebol nesses jornais online e os modos pelos quais elas disputam as interpretações coletivas sobre torcidas organizadas e torcedores, foram explorados em extensão em trabalho anterior.

É importante também salientar que este é apenas um entre muitos recortes possíveis e capazes de evidenciar a complexidade das múltiplas relações existentes entre a esfera do futebol e a da política. A título de exemplo, existem pesquisas orientadas para observar as relações institucionais de governos com a Confederação Brasileira de Futebol (CBF) (CALDAS, 1986; MÁXIMO, 1999; SOUZA, 2011), a construção de políticas públicas voltadas para torcedores

3 Para uma discussão aprofundada, a partir das Ciências Sociais, sobre a produção de representações sobre o real empírico pelo jornalismo e suas estratégias de legitimação, ver Da Silva (2007). Sobre o estudo do enquadramento midiático à ação coletiva, com enfoque em manifestações de 2013, ver Fernandes e Teixeira (2018). 
O ópio do povo? O futebol e as manifestações políticas no Brasil entre 2013 e 2020 Eric Monné Fraga de Oliveira

(SILVA et al., 2007; CAMPOS et al., 2008; CURI et al., 2008; NICÁCIO et al., 2009; REIS; LOPES; MARTINS, 2014), os direitos dos atletas do esporte (SÓCRATES; GOZZI, 2002; FLORENZANO, 2003; MARTINS; REIS, 2014) e a articulação de torcidas organizadas em luta por reconhecimento de seus direitos (TEIXEIRA, 2014; HOLLANDA; MEDEIROS; TEIXEIRA, 2015; OLIVEIRA, 2018). Também existem pesquisas a respeito da politização de torcedores em outros países, como Itália, Espanha, Holanda e Inglaterra (ARMSTRONG, 1998; SPAAIJ, 2006; FLORENZANO, 2014). Porém, embora estejam em crescimento, ainda são poucas as pesquisas que têm se preocupado em explorar se e em que condições o contexto do futebol pode ser capaz de oferecer aos torcedores-cidadãos a produção e circulação de interpretações da realidade social com potencial politizador.

Pretendemos argumentar que, embora "futebol" e "política" sejam categorias utilizadas para se referir a conjuntos distintos de relações sociais, significações e experiências coletivas e individuais, isso não implica que os universos abarcados por elas sejam inexoravelmente separados: sua autonomia relativa não é suficiente para que possuam existências mutuamente incomunicáveis no contexto social mais amplo em que se desenvolvem. Ao contrário, os intercruzamentos entre eles são múltiplos, dispersos, ambíguos e mesmo contraditórios.

\section{3- 2014: Não vai ter Copa}

Antes de alcançarmos 2013, é útil recordar um antecedente particularmente significativo em nossa história recente, narrado por Luiz Henrique de Toledo (2012). No dia 16 de dezembro de 1989, o Estádio do Morumbi presenciou a final do Campeonato Brasileiro, entre o São Paulo Futebol Clube e Clube de Regatas Vasco da Gama. Apesar de o país já ter realizado a lenta e prolongada transição para uma democracia representativa ${ }^{4}$ - com a pro-

4 Não é o propósito do presente artigo discutir os méritos dessa transição ou problematizar a noção de "democracia representativa". 
mulgação de uma nova Constituição um ano antes -, na entrada do estádio, a Polícia Militar exigia dos torcedores que não portassem nem exibissem propagandas políticas, enquanto confiscava dos torcedores adereços com estrelas vermelhas, símbolo do Partido dos Trabalhadores (PT).

No dia seguinte, domingo, 17 de dezembro, seria realizado o segundo turno das eleições presidenciais daquele ano - as primeiras eleições diretas para presidente após o golpe civil-militar de 1964. Na disputa, restavam apenas o ex-sindicalista Luiz Inácio Lula da Silva, do PT, e o ex-governador de Alagoas e futuro vencedor da disputa Fernando Collor de Melo, representante do então Partido da Reconstrução Nacional (PRN), atualmente Partido Trabalhista Cristão (PTC). A proibição das propagandas políticas pelos policiais militares contrastava com a presença de Lula no estádio, que encerrava sua campanha após uma última tentativa de angariar votos paulistas. Quando foi feito o anúncio da presença de Lula no Morumbi, "as arquibancadas se agitaram, ouviam-se vaias aqui e acolá, alguns torcedores próximos cantarolavam Collor, Collor" (TOLEDO, 2012, p. 124, grifo do original). Isso pode ser em parte explicado pela conhecida adesão de Lula ao Corinthians, não somando a nenhuma das torcidas presentes e inflamando a rivalidade local com o São Paulo. Para muitos torcedores, a manifestação política pode ocorrer mesmo durante um evento futebolístico.

Evento similar ocorreria no jogo de abertura da Copa do Mundo de 2014, realizada no Brasil, no dia 12 de junho, quando a então presidenta Dilma Vana Rousseff (PT) ouviu vaias e xingamentos da torcida brasileira que compareceu à Arena Corinthians, também conhecida como Itaquerão, na zona leste de São Paulo. Nos momentos de maior manifestação, ouvia-se um grande coro de parte dos torcedores, oriundos predominantemente das classes altas e médias, que gritavam "ei, Dilma, vai tomar no cu" (BOCCHINI, 2014). Os dois exemplos são casos emblemáticos de manifestações antipetistas dentro dos estádios de futebol, contra as quais não houve intervenção policial. 
A própria realização dos eventos da FIFA no país foi atravessada por debates na esfera pública, demonstrando que os eventos em si assumiram significados políticos. Em 15 de junho de 2013, no Estádio Nacional de Brasília "Mané Garrincha", foi inaugurada a Copa das Confederações. Dentro do estádio, a seleção brasileira bateu a japonesa por $3 \times 0$, enquanto se ouvia vaias à presidenta Dilma Rousseff (BISPO, 2013). Do lado de fora, havia manifestações contra os altos gastos federais relativos aos megaeventos no país (JÚNIOR, 2013).

Naquele momento, o país já vinha notando manifestações populares, com importante presença estudantil, desde o começo de junho. No dia 6, mais de 2000 pessoas participaram da manifestação organizada pelo Movimento Passe Livre em São Paulo, contrária ao aumento das tarifas de transporte público no município. Nos dias seguintes, as manifestações pela capital estadual cresceram, enquanto outras cidades presenciavam seus primeiros atos, com objetivos iguais ou similares, chegando no dia 14 a sete capitais, como Rio de Janeiro, Porto Alegre e Maceió (PALHANO, 2013). Parte da adesão das demais cidades foi consequência do que veio a ser chamado de "Batalha da Consolação", na qual houve forte repressão policial aos manifestantes, com pelo menos 200 detidos e 11 jornalistas feridos (STOCHERO ; PASSARINHO, 2014), aumentando a insatisfação popular.

Dois dias após o início da Copa das Confederações, as manifestações se intensificaram, expandindo-se para mais cidades, inclusive aquelas que não são capitais estaduais, e com o número de participantes chegando a cem mil em cidades como o Rio de Janeiro. Até o dia 21 de junho, quase 2 milhões de pessoas haviam ocupado as ruas de 438 cidades de todo o país (LEAL, 2013). Os protestos se repetiram apresentando um repertório variado (ALONSO; MISCHE, 2016) até o final do mês e receberam o nome de Jornadas de Junho (SINGER, 2013; BENZAQUEN, 2014). Durante esse período, os aumentos das tarifas de diversas cidades foram cancelados, mas, ao mesmo tempo, novas pautas da indignação coletiva vinham sendo progressivamente agregadas, enquan- 
to os protestos transbordavam "dos setores mobilizados para outras partes da sociedade" (BRINGEL; PLEYERS, 2015, p.18). Os manifestantes, adeptos de diversas posições no espectro político, chamavam a atenção para o contraste entre a má qualidade dos serviços públicos - especialmente nas áreas de educação, saúde, segurança e transporte - e os esforços e investimentos destinados à construção e remodelação dos estádios exigidos pela FIFA para a realização de suas competições no país. Havia ainda acusações de corrupção e superfaturamento nas obras dos estádios. Pautas locais foram fundidas a questões nacionais enquanto as manifestações eram reprimidas pelas polícias estaduais. Segundo o levantamento de Luciana Tatagiba e Andreia Galvão, houve no total 445 protestos no país em 2013 (2019, p. 70) - considerando também os protestos com outras pautas.

A expressão "padrão FIFA", indicadora do nível de excelência exigido pela entidade para as instalações que receberiam suas competições, passou a integrar o repertório de frases dos cartazes exibidos nos protestos - até mesmo dentro dos estádios onde se disputavam jogos da Copa das Confederações e, posteriormente, da Copa do Mundo. As manifestações exigiam escolas e hospitais "padrão FIFA". Sob a ótica dos manifestantes, se a FIFA poderia exigir um padrão tão alto do governo brasileiro, a população também poderia.

Em meio aos protestos, Aloizio Mercadante, então ministro da Educação, declarou que "O Nelson Rodrigues escreveu, há 30, 40 anos, que futebol e política não se misturam" (PASSARINHO, 2013). Embora se apresente formalmente como uma constatação de fato, que deveria ser julgada com base em sua adequação à realidade, 0 efeito perlocucionário (AUSTIN, 1962, p. 98) pretendido é normativo: que demandas políticas não sejam expressas no meio esportivo. Essa percepção que prevê uma incomensurabilidade absoluta entre esporte e política "estanca a relação entre adesão clubística e ideológica, entre paixões e vocações, era uma das heranças da cultura política do regime discricionário" (TOLEDO, 2012, p. 125). Toledo identifica a exigência de separação entre torcida e política 
como efeito de uma concepção autoritária sobre a vida pública, fazendo com que o indivíduo guarde para si suas interpretações do mundo político.

Nas semanas que se seguiram, a própria realização da Copa no país se tornou alvo dos protestos. Embora nunca tenha saído do repertório daquele momento, a frase "não é só por 20 centavos" (que fazia referência aos preços nos transportes públicos ao mesmo tempo em que previa que a discussão iria além), até então o lema dos protestos, perdeu o protagonismo para uma outra frase também surgida durante as Jornadas de Junho: "não vai ter Copa", versão reduzida dos cartazes que popularizaram a frase "se não tiver direitos, não vai ter Copa". Um manifesto com esse título foi lançado em 10 de dezembro de 2013 (BARROS, 2014), assinado por diversos movimentos sociais, entre os quais se destacam o Movimento Passe Livre, também responsável pelos protestos de junho de 2013, o Coletivo Autônomo dos Trabalhadores Sociais, o Periferia Ativa, o Comitê Contra o Genocídio da População Preta, Pobre e Periférica e o Fórum Popular de Saúde do Estado de São Paulo.

Em São Paulo, no dia 25 de janeiro de 2014, foi realizado o primeiro ato a trazer esse lema oficialmente. Parcialmente organizado através das redes sociais virtuais, o protesto terminaria com 128 manifestantes presos. Embora o debate continuasse vivo na esfera pública, novos atos viriam a acontecer apenas a partir de maio. No dia 27, aproximadamente duas semanas antes do jogo de abertura do mundial, 2500 pessoas - incluindo um grupo de 300 indígenas contrários às mudanças nas regras para demarcação de terras - se reuniram em Brasília para um novo protesto, duramente reprimido pela Polícia Militar. Uma pequena manifestação foi realizada em Goiânia, no dia 03 de junho, em frente ao hotel em que a seleção brasileira estava hospedada para enfrentar a seleção do Panamá em jogo amistoso. Três dias depois, uma nova manifestação na capital paulista, com doze mil pessoas, de acordo com a Polícia Militar, e 25 mil, de acordo com os organizadores, incluiu integrantes do Movimento dos Trabalhadores Sem Teto 
O ópio do povo? O futebol e as manifestações políticas no Brasil entre 2013 e 2020 Eric Monné Fraga de Oliveira

(MTST) (LACERDA et al., 2014; MOREIRA et al., 2014; CASTANHO, MEDEIROS ; PAIVA, 2014; MORA, 2014).

Em 12 de junho, dia da abertura oficial da Copa, ao menos sete capitais estaduais e a capital federal receberam protestos. Até o final da primeira semana, ocorreram ao menos vinte atos públicos, durante os quais 180 pessoas foram detidas. Entre 5 de junho e 6 de julho, 144 manifestações foram agendadas, em todas as doze cidades-sede da competição, sendo 47 no Rio de Janeiro, 28 em São Paulo, onze em Belo Horizonte, dez em Porto Alegre e em Fortaleza, nove em Brasília, sete em Recife e em Salvador, cinco em Natal e em Curitiba, três em Cuiabá e duas em Manaus. No dia do jogo final do mundial, os protestos foram marcados pela violência da ação policial, que feriu ativistas e ao menos dez jornalistas (G1, 2014a; 2014b; MAGALHÃES, 2014; PUFF ; KAWAGUTI, 2014).

Pouco antes do início da Copa, o Pew Research Center liberou um documento contendo uma pesquisa sobre o descontentamento brasileiro quanto à Copa do Mundo. A pesquisa revelou que para $61 \%$ dos brasileiros entrevistados receber a Copa era algo ruim porque concentrava o dinheiro que deveria ser destinado a serviços púbicos, enquanto 34\% alegavam que era algo bom, pois criaria empregos (2014, p. 5). Além disso, a confiança no papel do governo no país entre 2010 e 2014 caiu de 75\% para 47\% dos entrevistados (p. 7)

Entre o "não vai ter Copa" e o "vai ter Copa" estavam em jogo as representações sobre os significados do evento. Para os defensores da realização da Copa no país, ela proporcionava uma chance para aprofundar o desenvolvimento econômico, difundir uma imagem positiva do país no exterior, uma imagem de país moderno - algo similar às expectativas em torno da Copa de 1950. Para os opositores, ela representava corrupção e superfaturamento das obras, em detrimento dos serviços públicos e em privilégio de um pequeno grupo de empresas privadas que lucrariam com o evento (a FIFA e suas empresas parceiras). Para muitos opositores,

5 O relatório também revelou que $47 \%$ dos entrevistados acreditam que os protestos de 2013 foram positivos, pois trouxeram assuntos importantes para a discussão, enquanto $48 \%$ os interpretaram como negativos, pois propagaram uma imagem negativa do país para o mundo. 
O ópio do povo? O futebol e as manifestações políticas no Brasil entre 2013 e 2020

Eric Monné Fraga de Oliveira

os novos estádios implicavam na exclusão das formas populares de torcer - e os preços dos ingressos demonstrariam que a Copa não foi pensada para as classes mais baixas, constituindo-se como um objeto de consumo das classes médias e das elites. Em suma, para os defensores, a Copa significava modernização e desenvolvimento; para seus críticos, desprezo estatal pelos serviços públicos e submissão à excludente lógica de mercado.

Nesse contexto, o futebol e as percepções sobre ele serviram de espaço e mecanismo para a concretização de disputas e mobilizações políticas. Em alguns momentos, os próprios estádios se mostraram como espaços de manifestações políticas. Em outros, as competições e o vocabulário do esporte se tornaram catalizadores de manifestações populares. Nos anos seguintes, o esporte continuaria a pautar a gramática moral (HONNETH, 2009) dos protestos, porém de maneiras diferentes, uma vez que se abriam novos espaços na estrutura de oportunidades políticas (ROCHA, 2019, p. 20).

\section{4}

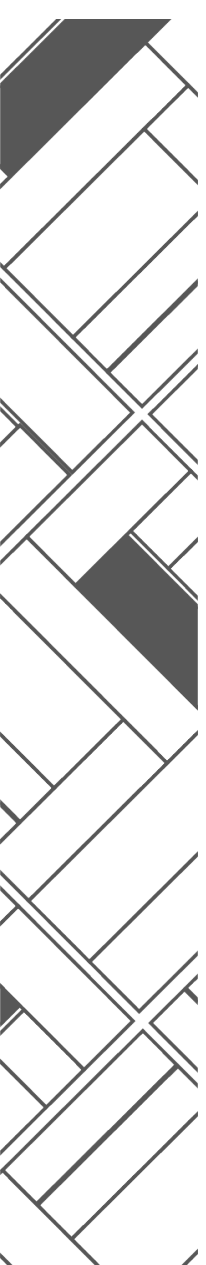

A partir do final de 2014, as manifestações mais frequentes nas ruas das grandes cidades brasileiras tomariam um novo rumo, contando com a participação e a organização de outros agentes políticos. As classes altas e médias, crescentemente contrariadas pelos programas e direitos sociais voltados para as classes subalternas durante os governos petistas (CAVALCANTE, 2015; SINGER ; LOUREIRO, 2016), ofendidas em sua crença na ideologia meritocrática, encontraram um caminho para a expressão de suas insatisfações a partir do repertório dos protestos de 2013 e 2014 , das eleições presidenciais de 2014 e da cobertura midiática da Operação Lava-Jato da Polícia Federal'. Nesse contexto, "as novas direitas passam a disputar as ruas, envolvendo grupos que com-

6 Discutir a fundo a crise dos governos petistas, a Operação Lava-Jato (seus possíveis méritos e deméritos) e o processo de impeachment ou golpe parlamentar sofrido pela ex-presidenta Dilma Rousseff não se encontra dentro do escopo do presente artigo. Entretanto, é impossível realizar a discussão aqui proposta sem pontuar alguns aspectos dessas questões. 
O ópio do povo? O futebol e as manifestações políticas no Brasil entre 2013 e 2020 Eric Monné Fraga de Oliveira

binam princípios e valores conservadores de modo distinto, mas que têm no antipetismo seu traço comum" (TATAGIBA ; GALVÃO, 2019, p. 78).

O primeiro protesto pedindo o impeachment da então presidenta foi realizado em 01 de novembro de 2014, apenas seis dias após sua reeleição. Convocado por Paulo Batista, candidato derrotado a deputado estadual naquela ocasião, o ato reuniu 2500 pessoas em São Paulo, segundo os veículos de imprensa (CHAPOLA, 2014; URIBE, LIMA; LIMA, 2014). O protesto contou com celebridades da nova direita, como o cantor Lobão e o deputado federal Eduardo Bolsonaro, além de ter recebido o apoio virtual do astrólogo Olavo de Carvalho (ROCHA, 2019). Os manifestantes faziam acusações diversas ao PT - sobretudo de envolvimento em corrupção, construção de uma ditadura e fraude das eleições -, mas se uniam ao pedir o impeachment como solução principal, embora sem propor algum embasamento factível ${ }^{7}$.

Outro elemento que unificaria os manifestantes a partir de então foi o uso dos símbolos pátrios. Além da bandeira do Brasil, boa parte vestia roupas amarelas, verde-amarelas ou azuis, especialmente camisas oficiais da seleção brasileira. Outras camisas tradicionalmente utilizadas por torcedores em dias de jogo da seleção, assim como outros itens de indumentária nas mesmas cores também podiam ser vistos. Muitos dos presentes traziam as cores nacionais pintadas no rosto, diversos portavam perucas, cornetas e/ou vuvuzelas verde-amarelas. Havia também, como em qualquer jogo da seleção, pessoas vestidas em cores neutras ou com camisas de seus próprios clubes. Essa estética adotada pelos manifestantes se fortaleceria nos protestos seguintes até que a presidenta fosse removida do cargo. Ainda nos primeiros protestos, grupos organizados virtualmente que compunham a

7 Um golpe militar também era apresentado por uma parcela dos manifestantes como uma forma de remover o PT do governo federal. 
O ópio do povo? O futebol e as manifestações políticas no Brasil entre 2013 e 2020

Eric Monné Fraga de Oliveira

nova direita ultraliberal ${ }^{8}$ assumiram protagonismo cada vez maior (ROCHA, 2019, p. 25) ${ }^{9}$.

Simoni Lahud Guedes e Edilson Márcio Almeida da Silva (2019) argumentam que esse processo significou um segundo sequestro das cores e símbolos pátrios pela direita. Historicamente, a relação entre povo e os símbolos pátrios é particularmente complexa no Brasil. Originalmente, tais símbolos eram considerados não como oriundos da população, mas como propriedades do Estado e, portanto, das elites e dos militares que o dirigiam. O futebol exerceu um papel tão importante na apropriação dos símbolos e cores nacionais pelo povo que Roberto DaMatta chega a afirmar que "foi só com o futebol que conseguimos, no Brasil, somar Estado nacional e sociedade" (1994, p. 17). A participação da seleção nacional na Copa de 1970 foi um marco nesse processo, com torcedores desafiando as normas rígidas do regime ao apresentarem, durante a competição, bandeiras improvisadas artesanais e outros adereços nas cores nacionais, "ao passo que a indústria pouco a pouco providenciava camisas e todo tipo de artefatos (sandálias, cangas, bandanas, guarda-sóis etc.) [...]. Muitas vezes, ruas foram pintadas nas cores da bandeira" (GUEDES; DA SILVA, 2019, p. 76). Nas décadas que se seguiram, apesar dos graus variáveis de entusiasmo popular e da extensão da confecção artesanal e industrial desses artefatos, o uso das cores e símbolos nacionais para adornar corpos, residências, lojas, restaurantes, ruas e demais ambientes públicos tornou-se parte importante do ritual nacional que consiste em acompanhar a seleção, concebida como uma incorporação da nação, durante a Copa do Mundo ${ }^{10}$. Contudo, após as Jornadas de Junho, partidos e movimentos de direita que buscam se estabelecer como herdeiros do legado desse ciclo de manifestações se

\footnotetext{
8 Segundo Rocha (2019), a categoria "ultraliberal" é utilizada para demarcar pessoas e grupos que defendem "a primazia da lógica de mercado sob argumentos morais". Não pretendemos abordar, dados os limites do presente artigo, a relação entre o ultraliberalismo de mercado e o conservadorismo político.

9 Entre esses grupos, chama-se a atenção para o Líber, a Renovação e, sobretudo, o Movimento Brasil Livre, que viria a eleger diversos representantes em níveis distintos da política nacional nos anos seguintes, sempre baseados na plataforma antipetista e procurando se legitimar através de um discurso anticorrupção.

10 Segundo Guedes e da Silva (2019, p.78), essa identificação seleção brasileira = povo = nação tem se corroído desde a década de 1990, com a explosão da mercantilização dos jogadores de futebol, em um processo que levou contingentes crescentes de jogadores brasileiros para os clubes europeus e os transformou em celebridades.
} 
apropriaram novamente das cores e símbolos pátrios, afastando-os do restante da população.

É importante reforçar que houve diversas transformações entre o que se presenciou entre 2013 e 2014, de um lado, e do final de 2014 até 2016, do outro, especialmente no que diz respeito à pluralidade dos manifestantes, aos grupos socioeconômicos atuantes, às pautas prioritárias e secundárias e aos partidos políticos e movimentos sociais interessados (CAVALCANTE, 2015; TATAGIBA; GALVÃO, 2019). Aqui, restringimo-nos a observar apenas a que diz respeito ao universo do futebol. Em 2013, as manifestações questionavam os gastos públicos com a realização da Copa do Mundo. Entre o final de 2013 e meados de 2014, elas se posicionavam abertamente contra a competição. Já a partir do final de 2014, a crítica às competições e seu legado perdeu centralidade, enquanto a estética de torcedores de futebol passou a ser utilizada ostensivamente e a servir como um agregador de uma forma específica de insatisfação, que começou a se notar ainda durante as partidas da Copa, dentro dos estádios, com os xingamentos e vaias contra a presidenta, oriundos de uma parcela privilegiada da população. Ademais, também se deve notar que as críticas não eram mais contra aspectos, políticas ou decisões do governo, mas contra o próprio governo, visando a derrubá-lo.

Vestidos de amarelo, verde e azul, os manifestantes procuravam incorporar um espírito patriótico, como se suas pautas se identificassem com as necessidades de todos. Eles seriam os "verdadeiros torcedores" da nação, opondo-se àqueles que supostamente a prejudicariam propositalmente - percepção presente nos cartazes que atribuíam ao PT a alcunha de "o câncer do Brasil". Em oposição, estariam os "vermelhos", os "comunistas" e os "petralhas", que deveriam "ir para Cuba" ou "para Venezuela", como indicavam as frases de ordem das manifestações. Junto ao slogan "nossa bandeira jamais será vermelha", essas frases mobilizavam um discurso de "nós-brasileiros" contra "eles", que, por oposição, seriam traidores da pátria, não brasileiros verdadeiros. 
O ópio do povo? O futebol e as manifestações políticas no Brasil entre 2013 e 2020 Eric Monné Fraga de Oliveira

Essa forma altamente polarizada e polarizadora de interpretação do mundo social baseia-se na metáfora torcedora, como os trajes dos manifestantes denotam, a partir de uma interpretação maniqueísta das oposições entre torcedores rivais. Para um corintiano, é bem claro que existe uma diferença entre ele e um palmeirense: eles se vestem diferentemente em dia de jogo (em alguns casos, em dia de treino também), possuem objetivos paralelos enquanto animam suas equipes, são movidos por emoções e interesses distintos - de forma que o sucesso e a felicidade de um, em muitos momentos, serão dependentes do fracasso e da tristeza do outro. Situação parecida, embora, em geral, de forma menos radical, ocorre quando seleções nacionais pelejam umas contra as outras na Copa do Mundo: os torcedores de cada uma se vestem conforme as cores do país e procuram incentivar o próprio time rumo à vitória, de forma que todo adversário, por definição, torna-se temporariamente um inimigo da nação - ou melhor, daquela representação imaginada e contextualizada da nação -, cuja presença na competição precisa ser encerrada com uma derrota em campo.

A estratégia de representação assumida pelos manifestantes pró-impeachment consistiu na emulação de uma estética de torcida da seleção brasileira, transposta para o ambiente de protestos políticos, produzindo uma "identidade coletiva" (MELUCCI, 1995) enquanto "patriotas legítimos", implicando na oposição entre eles e seus opositores, aos quais são destinados rótulos negativos baseados nas piores características atribuídas a seus piores supostos membros (ELIAS; SCOTSON, 2000) ${ }^{11}$. Cabe também notar que os protestos contrários ao impeachment e em defesa da então presidenta não procuraram mobilizar os símbolos pátrios como agregadores e identificadores: já sabendo que seus opositores os utilizavam, evitava-se que fossem confundidos publicamente com eles. A partir de 2014, o grupo favorável à deposição da presidenta presenciou um crescimento substancial e se tornou mais radica-

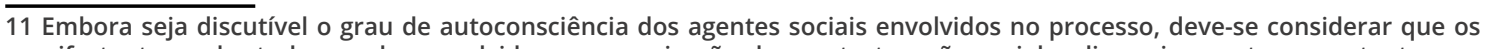
manifestantes, sobretudo aqueles envolvidos na organização dos protestos, são social e discursivamente competentes em mobilizar e manter os símbolos mais eficientes para os efeitos discursivos e políticos almejados. 
O ópio do povo? O futebol e as manifestações políticas no Brasil entre 2013 e 2020

Eric Monné Fraga de Oliveira

lizado, agregando ao antipetismo primeiro o anticomunismo e posteriormente o bolsonarismo ${ }^{12}$, o qual serviu como um caminho político capaz de vencer eleitoralmente tanto o PT quanto as alternativas de direita mais tradicionais.

Após a saída de Dilma Rousseff da presidência, em 31 de agosto de 2016, as manifestações nacionalistas antipetistas passaram por um período de incertezas, no qual suas pautas se tornaram mais difusas, mas não arrefecidas. Nos pleitos municipais daquele ano, foram eleitos diversos de seus principais representantes e articuladores. Contudo, em 2018, com a campanha presidencial de Jair Bolsonaro pelo Partido Social Liberal, muitos desses manifestantes novamente se agregaram em torno de um discurso que incorporava o antipetismo e o anticomunismo enquanto alguns dos elementos organizadores centrais de sua plataforma política. Em resposta ao movimento \#EleNão - que começou nas redes sociais e observou seu maior ato em 29 de setembro de 2018, com mais de 2,5 milhões de pessoas, em 160 cidades (UNIVERSA, 2018; DARLINGTON, 2018, TOLEDO, 2018) -, contrário ao candidato da extrema-direita, os grupos favoráveis a Bolsonaro voltaram a vestir suas camisas verde-amarelas, amarelas e azuis, realizando manifestações \#EleSim em 40 cidades no dia 29 de setembro de 2018, e em 20 cidades no dia 30, com 1,8 milhão de pessoas, segundo os organizadores (G1, 2018a; 2018b; BORGES ; DELLA COLETTA, 2018; ESTADO DE MINAS, 2018). Nos últimos anos, tem-se debatido na esfera pública e no ambiente acadêmico se e em que medida o bolsonarismo pode ser identificado como uma nova face do fascismo à brasileira.

\footnotetext{
12 Para os fins do presente artigo, trabalharemos, a partir de Cesarino (2019), Araújo (2019) e Almeida (2019), com uma definição preliminar do fenômeno, ainda muito recente, do bolsonarismo enquanto a conciliação, em torno da figura de Jair Bolsonaro e sua família, entre um conservadorismo moralista e antimoderno de matriz fundamentalista cristã, uma plataforma econômica elitista ultraliberal e uma retórica paramilitar de extermínio da oposição. Entretanto, não se deve esquecer que existem diversas características que compõem, de maneiras desiguais, essa categoria política, como a retórica anticorrupção e lavajatista, o desprezo pelas ciências enquanto formas de produção de conhecimento e o ódio pelas minorias políticas. Contudo, consideramos que elas reforçam os três elementos centrais que destacamos.
} 


\section{8-2020:Torcidas antifascistas e a defesa da democracia}

Analisar o bolsonarismo enquanto fenômeno político e discutir a pertinência do termo fascismo para explicá-lo, assim como procurar definir com precisão a própria categoria "fascismo", é uma tarefa que envolve pesquisas e discussões que, conquanto importantes, não cabem no propósito do presente artigo ${ }^{13}$. Embora não haja atualmente um consenso acadêmico no que tange esses debates, no caso do futebol pôde-se observar a proliferação de torcidas autointituladas "antifascistas" ao longo dos últimos anos. Em parte, elas reagem ao panorama social, cultural e político, também visível no futebol, de avanço contínuo de pautas determinadas pelos setores mais à direita da sociedade, unificadas tanto em torno do antipetismo que resultou no golpe parlamentar que destituiu Dilma Rousseff da presidência da república (SANTOS, 2017) quanto no bolsonarismo que culminou na eleição de Jair Bolsonaro à presidência e de diversos de seus asseclas a outros cargos políticos em 2018. Essas pautas apresentam em comum um caráter moralista, privatizador e elitista, muitas vezes calcadas no fundamentalismo religioso e em um discurso ultranacionalista - como evidenciado pelo slogan de campanha de Bolsonaro em 2018: "Brasil acima de tudo, Deus acima de todos".

Para todos os efeitos, escolhemos por abordar o "antifascismo" dessas torcidas como uma categoria nativa, nos termos de Clifford Geertz (1989), uma vez que são pessoas comuns que a estão mobilizando em suas vidas sociais e a tornando parte da estrutura de significado que organiza suas mobilizações políticas. Segundo reportagem do jornal El País, havia, em 25 de dezembro de 2019, em torno de 60 agrupamentos de torcedores que se identificam como antifascistas no país (MAGRI, 2019). Essas torcidas, que não veem a si mesmas como "torcidas organizadas", articulam os debates a respeito de futebol - preferencialmente sobre os clubes pelos quais torcem - a questões políticas e sociais como a luta contra

13 Para uma discussão complexa sobre as conceituações acadêmicas sobre o fascismo, ver Pinto (2006). Já para uma análise sobre a pertinência do conceito de "fascismo" para compreender o avanço dos movimentos contemporâneos de extrema-direita, ver Traverso (2019). 
o racismo, o machismo e a homofobia. Suas discussões adotam também um posicionamento crítico em relação ao capitalismo enquanto sistema econômico, político e social que se relaciona com as demais formas de dominação e que é responsável por mudanças de caráter elitista e excludente no futebol, presentes desde antes do avanço da extrema-direita a partir de 2016.

Essas transformações podem ser vistas no aumento de preços dos ingressos de jogos no Estádio Jornalista Mário Filho, o Maracanã. Martin Curi (2012, p. 64) constatou que, entre 2000 e 2010, o preço dos ingressos das arquibancadas verde e amarela subiu de $R \$ 10,00$ e $R \$ 15,00$, respectivamente, para $R \$ 40,00$ ambas. Na arquibancada branca, cada ingresso foi de $R \$ 25,00$ para $R \$ 50,00$. Na cadeira especial, o preço subiu de $R \$ 120,00$ para $R \$ 150,00$. Embora isso pudesse ser parcialmente explicado pelo crescimento do valor do salário mínimo no país durante o período - de $R \$ 136,00$ para $R \$ 510,00$-, o aumento real do preço dos ingressos mais baratos durante o período foi notável, uma vez que foi extinta a geral, setor mais barato, onde os ingressos custavam, em 2000, entre $R \$ 1,00$ e $R \$ 3,00$. Considerando que, entre 2000 e 2009 o preço do segundo setor mais barato, a cadeira comum, subiu de $R \$ 5,00$ para $R \$ 20,00$ e que em 2010 essa seção esteve fechada para reforma, é possível concluir que o valor mais barato a ser desembolsado para se assistir a um jogo no Maracanã aumentou de $\mathrm{R} \$ 1,00-3,00$ em 2000 para $\mathrm{R} \$ 20,00$ em 2009 e $\mathrm{R} \$ 40,00$ em 2010 - crescimento proporcionalmente muito superior ao do salário mínimo e ao da inflação no mesmo período. Essa tendência seria vista em todo o país com a aproximação da Copa do Mundo de 2014.

Em anos mais recentes, a política de preço de ingressos esteve relacionada aos programas de sócio-torcedor. Para jogo contra o Coritiba Foot Ball Club, válido pelo Campeonato Brasileiro de 2016 no Maracanã, os ingressos mais baratos oferecidos pelo Clube de Regatas do Flamengo eram destinados exclusivamente aos sócios-torcedores: $\mathrm{R} \$ 40,00$ para os consumidores dos planos Raça ou superiores; $\mathrm{R} \$ 60,00$ para quem optou pelo plano Tradição. Para 
O ópio do povo? O futebol e as manifestações políticas no Brasil entre 2013 e 2020 Eric Monné Fraga de Oliveira

o público geral, os ingressos mais baratos estavam em $\mathrm{R} \$ 80,00$, enquanto os mais caros chegavam a $\mathrm{R} \$ 225,00^{14}$ (GLOBOESPORTE. COM, 2016). Designado ao ambiente do consumo, o torcedor fica exposto ao funcionamento do mercado, intensificando o processo de transformação do futebol em uma mercadoria, situação criticada e combatida pelas torcidas antifascistas.

Embora cada torcida atue de forma diferente, de acordo com seu contingente e com os objetivos e necessidades que sentem em seus contextos, foi possível registrar quatro formas principais através das quais essas torcidas se relacionam com seu entorno: 1) fora dos estádios, em ações conjuntas com outros movimentos sociais, como movimentos feministas e movimentos negros; 2) dentro dos estádios, confrontando torcedores que apresentem comportamentos discriminadores contra alguma minoria ali presente, sobretudo racismo, machismo ou homofobia; 3) tanto dentro quanto fora dos estádios, em manifestações independentes por ingressos de preço acessível ou orientadas em torno de pautas políticas; 4 ) em redes sociais virtuais, com publicações que abordem temáticas cujo debate é caro às torcidas antifascistas.

Embora essas torcidas tenham começado a se proliferar desde 2014 (à exceção da Ultras Resistência Coral, torcida do Ferroviário Atlético Clube, de Fortaleza, fundada em 2005 e em geral considerada como a torcida antifascista mais antiga do país), suas ações e sua visibilidade se intensificaram desde 2018. Na ocasião, diversas torcidas organizadas aderiram ao movimento \#EleNão contra Jair Bolsonaro. Ademais, ressalta-se também que a torcida Esquerda Vascaína declarou apoio a Tarcísio Motta, candidato ao governo do Estado do Rio de Janeiro pelo Partido Socialismo e Liberdade (PSOL). Ao longo de 2019, as torcidas antifascistas continuaram sua atuação nos estádios e online, buscando maior visibilidade e aumentar seus números para se envolverem em ações de maiores proporções.

A partir de maio de 2020, após mais de um ano do governo de Bolsonaro, os integrantes de diversas torcidas organizadas convo-

$\overline{14 \text { Valores integrais. }}$ 
caram, junto às torcidas antifascistas, manifestações públicas em protesto contra o presidente e o panorama sociocultural, político-ideológico e econômico que o acompanha. No dia 31 daquele mês, quando o Brasil já havia ultrapassado as 29 mil mortes oficiais e os 500 mil casos oficiais decorrentes da pandemia do novo coronavírus (COVID-19) (CATRACA LIVRE, 2020), membros de torcidas organizadas como a Gaviões da Fiel, do Corinthians, da Mancha Alviverde, do Palmeiras, e da Torcida Tricolor Independente, do São Paulo, e da Torcida Jovem do Santos, junto ao grupo Porcomunas, do Palmeiras, e às torcidas antifascistas dos quatro maiores times do estado, tomaram o vão do Museu de Arte de São Paulo (MASP), na Avenida Paulista, para realizar uma manifestação contra o presidente.

Manifestações similares puderam ser vistas naquele dia em outras cidades do país. No Rio de Janeiro, as torcidas antifascistas de Botafogo, Flamengo, Fluminense e Vasco também levaram suas faixas em defesa dos valores democráticos. O mesmo ocorreu em Belo Horizonte, Porto Alegre e Salvador (CASSUCCI; FERNANDEZ, 2020), com membros das torcidas dos maiores times das cidades se articulando a partir de uma indignação em comum. Isso não significa que os antagonismos tenham sido superados. Há relatos de tensão e animosidades entre membros das torcidas com maior rivalidade (CASSUCCl; FERNANDEZ, 2020), mas não houve maiores distúrbios internos, de forma que as pautas comuns foram tomadas como mais importantes naquele momento do que as desavenças.

Todavia, apesar da presença de seus membros e da posição política expressa de algumas de suas lideranças, as torcidas organizadas não apoiaram oficialmente as manifestações. Alguns líderes chegaram a pedir que seus integrantes não portassem nada que identificasse as organizadas (PETROCILO; SABINO, 2020). Em primeiro lugar, porque reconhecem que os grupos são formados por indivíduos que demonstram uma multiplicidade de convicções políticas, receando que, em um ambiente sociopolítico tão polarizado, uma tomada de posicionamento possa causar uma ruptura 
definitiva em seus grupos. Isso quase aconteceu em 2018, quando líderes de 69 torcidas, incluindo organizadas, receberam críticas internas ao assinarem um manifesto em defesa da campanha de Fernando Haddad (PT), principal adversário de Bolsonaro nas eleições daquele ano (WILKSON, 2018). Uma ruptura desse tipo as prejudicaria na disputa pela legitimidade de representação da torcida do time, tarefa central às torcidas organizadas (OLIVEIRA, 2018). Em segundo lugar, também existe o receio de que, caso haja distúrbios envolvendo seus membros e repressão policial, as torcidas organizadas sejam penalmente responsabilizadas, o que é previsto pelo Estatuto do Torcedor (BRASIL, 2003).

Três dias antes dos protestos, a reprovação ao governo do presidente Jair Bolsonaro alcançara novo recorde, subindo a 43\%, segundo o Instituto de Pesquisas Datafolha (OPINIÃO PÚBLICA, 2020). A pandemia de COVID-19 levou à deterioração da situação econômica, ao aprofundamento da instabilidade institucional e política e à iminência de uma crise na saúde pública. A situação produziu um novo quadro de insatisfação coletiva no país, como verificado pelos frequentes panelaços contra o presidente nas primeiras semanas de quarentena $(G 1,2020)$. No caso dos torcedores, cujas relações interpessoais já vinham sendo afetadas pelas mudanças na economia política do esporte no país, a insatisfação teve o acréscimo da suspensão das atividades esportivas presenciais. Embora essa decisão tenha sido entendida como legítima e justificada, a má administração da pandemia pelo governo foi considerada como responsável pelo agravamento de um quadro já ruim, prejudicando ainda mais todos os aspectos da vida social. Os grupos de torcedores antifascistas realizaram as primeiras manifestações públicas contra Bolsonaro desde o começo da pandemia no país, mas, não obstante as manifestações subsequentes (ESTADO DE MINAS, 2020; G1 RIO, 2020; OLIVEIRA, 2020; MARIN, 2020; UOL, 2020, REDE BRASIL ATUAL, 2020), ainda serão necessários mais tempo e novas pesquisas para identificar se constituíram o começo de um novo ciclo de protestos no país e seus impactos.

Nesses casos especificamente, notou-se que o contexto das torcidas de futebol demonstrou-se como propício para o sur- 
O ópio do povo? O futebol e as manifestações políticas no Brasil entre 2013 e 2020 Eric Monné Fraga de Oliveira

gimento de vínculos de solidariedade baseados em afinidade político-ideológica. Essa solidariedade levou à formação de coletividades guiadas por objetivos em comum que transcendem os limites da paixão clubística. Embora não superem os antagonismos entre os torcedores de times rivais, esses grupos ofereceram uma nova forma de mobilização e articulação, capaz de focalizar os interesses e metas que possibilitam ações conjuntas, em detrimento das formas que incentivam a rivalidade. Se, por um lado, a filiação clubística permanece como um aspecto central de suas identidades - tanto individuais quanto coletivas -, por outro o posicionamento político cria laços que possibilitam a comunicação, tanto no sentido de transmissão de mensagens quanto no sentido de compartilhamento de significados comuns.

\section{Considerações finais}

Ao longo do presente artigo, procuramos debater sobre as múltiplas formas como o futebol constituiu parte importante da gramática de diversas manifestações políticas no país entre 2013 e 2020. Nosso intuito foi demonstrar que torcer por um time de futebol ou mesmo pela seleção nacional não constitui intrinsecamente e por si só uma atividade "alienante", uma vez que não necessariamente demove um sujeito da realidade social em que existe, podendo abrir espaços para uma produção potencial de novos tipos de laços sociais. Isso não significa que o futebol sempre possibilite reflexões sobre a realidade social mais ampla, em todo e qualquer contexto. Diversas formas de articulação do futebol com o universo político são possíveis, mas isso dependerá das maneiras pelas quais os agentes (torcedores, ativistas, manifestantes, políticos profissionais, jornalistas, intelectuais, pesquisadores etc.) levem a cabo suas práticas, travem suas relações mútuas e mobilizem os quadros interpretativos disponíveis que eles, ao mesmo tempo, reproduzem e transformam.

Em um primeiro momento, avaliamos como os gastos públicos em torno de eventos de futebol mobilizaram uma campanha 
O ópio do povo? O futebol e as manifestações políticas no Brasil entre 2013 e 2020 Eric Monné Fraga de Oliveira

de indignação coletiva, que contrastava o volume de tais gastos com o investimento abaixo do desejado em pautas sociais como educação, saúde e transporte público ${ }^{15}$. Assim, o futebol se tornou um objeto das disputas sociopolíticas, culturais e simbólico-narrativas dos manifestantes, do governo e dos meios de comunicação, ao mesmo tempo em que foi ressignificado como parte da gramática moral dos protestos. A importância do futebol e dos eventos concernidos no debate público e na vida social no Brasil constituiu uma oportunidade para a mobilização de protestos coletivos.

No período seguinte, o futebol deixou de ser um dos centros gravitacionais em torno dos quais eram articulados e mobilizados os discursos e atos na esfera pública, mas ainda se fazia muito presente. Durante as manifestações que objetivavam a destituição de Dilma Rousseff da presidência da república, a estética da torcida de futebol foi adotada pelos participantes. $\mathrm{O}$ efeito pretendido era traduzir a ideia de que eles seriam "verdadeiros torcedores" da nação brasileira, apelando ao senso de comunidade e induzindo ao pensamento de que seus opositores, incluindo a própria presidenta, não seriam verdadeiramente brasileiros. Isso pode ser notado pela sucessão de slogans como "minha bandeira jamais será vermelha", "meu partido é o Brasil" e "Brasil acima de tudo", visíveis desde o começo dos atos contra a então presidenta até as manifestações em defesa da candidatura e, em seguida, da atuação de Jair Bolsonaro na presidência. Significativamente, até slogans ufanistas utilizados durante o regime militar, como "Brasil: ame-o ou deixe-o" e "Pra Frente, Brasil" - este último em alusão à seleção de futebol nacional, em uma operação que identifica seleção e nação - foram ressuscitados por uma emissora de televisão em 2018 (SACCHITIELLO, 2018).

Por fim, demonstramos que os contextos em que os torcedores produzem suas relações sociais recíprocas em torno de seus times de coração são também propícios à criação de grupos orientados para a mobilização política. O futebol aqui é menos o objeto

\footnotetext{
15 Contudo, deve-se notar que, a partir de 2003 e até 2015, período em que a presidência da república foi ocupada pelo Partido dos Trabalhadores, houve um aumento dos investimentos em educação, de R\$19,8 bilhões em 2003 para R $\$ 127,9$ bilhões em 2015. Ajustando esses números à inflação até 2016 , o aumento foi de $R \$ 42,1$ bilhões para $R \$ 137,2$ bilhões, ou seja, pouco mais que o triplo (MEDEIROS, 2016).
} 
da disputa de significado (embora ainda o seja, uma vez que esses sujeitos debatem também o papel social do esporte) ou uma fonte estética orientada para produzir um efeito interpretativo específico do que o momento e o lugar sociocultural em que a politização acontece de fato. Nesse caso, a identidade torcedora serve como inserção para uma identidade cidadã, e as relações sociais entre esses sujeitos passam a ser permeadas não apenas por afinidades clubísticas, mas também por debates políticos e socioculturais. Em vez de pura e simplesmente alienarem os cidadãos, essas relações e identidades são construídas coletivamente de forma a capacitar que os sujeitos reconheçam os espaços sociais que ocupam enquanto atravessados por relações de poder desiguais e hierárquicas, mas passíveis de serem disputados. Nas palavras de Axel Honneth, "o engajamento individual na luta política restitui ao indivíduo um pouco de seu autorrespeito perdido" (2009, p. 259260) - no presente caso, enquanto torcedores e cidadãos.

Embora diversos enfoques sobre a relação entre futebol e política sejam possíveis, aqui optamos por três variações peculiares verificadas ao longo da última década. Por um lado, elas contemplam posições distintas do espectro político, o que implica em inserções de classe divergentes e por vezes antagônicas. Por outro, demonstram diferentes percepções não apenas a respeito de questões mais tradicionalmente compreendidas como políticas, como também sobre o papel e o significado da torcida e do futebol na sociedade brasileira. A história do futebol no país mostra que ele pode servir como prática de distinção das elites, como reprodução de formas de dominação de raça, gênero, classe, sexualidade e religião, como inspiração para movimentos antidemocráticos, como mecanismo de legitimação de um regime autoritário. Mas, ao participar das disputas pelas interpretações da realidade social, o contexto do futebol também pode, por outro lado, oferecer múltiplas formas de cidadania e politização ausentes ou deficitárias em outros espaços da vida social do país, desde que aqueles que desejam a diminuição ou extinção das desigualdades sociais não se recusem a disputá-lo e ocupá-lo. 


\section{Referências}

32XSP. O Brasil precisa se livrar do Fla-Flu político. Carta Capital, 24 set. 2013. Disponível em: https://www.cartacapital.com.br/politica/o-brasil-precisa-se-livrar-do-fla-flu-politico-4749/. Acesso em: 03 ago. 2020.

ALABARCES, Pablo. Fútbol y patria: el fútbol y las narrativas de la nación en la Argentina. Buenos Aires: Prometeo, 2002.

ALMEIDA, Ronaldo de. Bolsonaro presidente: conservadorismo, evangelismo e a crise brasileira. Novos estudos CEBRAP, São Paulo, v. 38, n. 1, p. 185-213, 2019.

ALONSO, Angela; MISCHE, Ann. Changing repertoires and partisan ambivalence in the new brazilian protests. Bulletin of Latin American Research, v. 36, n. 2, pp. 144-159, 2016.

ARAÚjO, Wécio P. Estado, ideologia e capital no Brasil contemporâneo: contradições do lulismo e surgimento do bolsonarismo. Cadernos de Ciências Sociais da UFRPE (Dossiê: O Golpe de 2016 e o futuro da democracia) - Ano VII, v. II, n. 13 (jul./dez. 2018). - Recife: EDUFRPE, 2019, p. 13-32.

ARMSTRONG, Gary. Football hooligans - knowing the score. Oxford: Berg, 1998.

AUSTIN, John Langshaw. How to do things with words - the William James lectures delivered at Harvard University in 1955. Oxford: Oxford University, 1962.

BALL, Phil. Morbo: the story of Spanish football. Londres: WSC, 2001.

BARROS, Ciro. Conheça os ativistas que gritam "não vai ter Copa". UOL, 20 fev. 2014. Disponível em: https://copadomundo.uol.com. br/noticias/redacao/2014/02/20/conheca-os-ativistas-que-gritamnao-vai-ter-copa.htm\#fotoNav=18. Acesso em: 15 mar. 2017. 
O ópio do povo? O futebol e as manifestações políticas no Brasil entre 2013 e 2020 Eric Monné Fraga de Oliveira

BENZAQUEN, Guilherme Figueredo. O pouco que sabemos de junho. Enfoques, v.13, pp.73-102, jun. 2014.

BISPO, Fábio. Cronologia das manifestações em Florianópolis e no País. NDONLINE, 22 jun. 2013. Disponível em: https:// ndonline.com.br/florianopolis/noticias/cronologia-das-manifestacoes-em-florianopolis-e-no-pais. Acesso em: 14 mar. 2017.

BOCCHINI, Lino. Lições do “Ei, Dilma, vai tomar...". Carta Capital, 13 jun. 2014. Disponível em: https://www.cartacapital.com.br/ politica/licoes-do-201cei-dilma-vai-tomar.201d-8226.html. Acesso em: 13 mar. 2017.

BORGES, Rodolfo; DELLA COLETTA, Ricardo. Após ameaça na TV, Bolsonaro diz agora que não há "nada para fazer" se perder. El País, 21 out. 2018. Disponível em: https://brasil.elpais.com/brasil/2018/09/30/politica/1538312667_597094.html. Acesso em: 16 set. 2020.

BRASIL. Lei $\mathbf{n . 1 0 . 6 7 1}$, de 15 de maio de 2003. Dispõe sobre o Estatuto de Defesa do Torcedor e dá outras providências. Estatuto de Defesa do Torcedor, Brasília, DF, maio 2003.

BRINGEL, Breno; PLEYERS, Geoffrey. Junho de 2013... dois anos depois. Polarização, impactos e reconfiguração do ativismo no Brasil. Nueva Sociedad, novembro de 2015.

CALDAS, Waldenir. O futebol no país do futebol. Lua Nova, São Paulo, v. 3, n. 2, p. 24-30, 1986.

CAMPOS, Priscila Augusta Ferreira et al. As determinações do Estatuto de Defesa do Torcedor sobre a questão da violência: a segurança do torcedor de futebol na apreciação do espetáculo esportivo. Revista Brasileira de Ciências do Esporte, Campinas, v.30, n.1, p.9-24, 2008.

CASTANHO, Fábio de Mello; MEDEIROS, João Paulo; PAIVA, Celso. Protesto contra Copa leva confusão à rua de hotel do Brasil.

Terra, 3 jun. 2014. Disponível em: http://esportes.terra.com.br/ brasil/protesto-contra-copa-reune-30-pessoas-em-hotel-da-se- 
lecao,e878c0483e166410VgnVCM3000009af154d0RCRD.html. Acesso em: 16 mar. 2017.

CASSUCCI, Bruno; FERNANDEZ, Martín. Democracia e antifascismo: quem são os torcedores que realizaram protestos pelo Brasil no domingo. Globo Esporte, 02 jun. 2020. Disponível em: https:// globoesporte.globo.com/sp/futebol/noticia/democracia-e-antifascismo-quem-sao-os-torcedores-que-realizaram-protestos-pelo-brasil-no-domingo.ghtml. Acesso em: 25 ago. 2020.

CATRACA LIVRE. Brasil tem mais de 29 mil mortes por coronavírus neste 31 de maio. Catraca Livre, 31 mai. 2020. Disponível em: https://catracalivre.com.br/saude-bem-estar/brasil-tem-mais-de-29-mil-mortes-por-coronavirus-neste-31-de-maio/. Acesso em: 25 ago. 2020.

CAVALCANTE, Sávio. Classe média e conservadorismo liberal. In: CRUZ, Sebastião Velasco e; KAYSEL, André; CODAS, Gustavo. (orgs.). Direita, volver! O retorno da direita e o ciclo político brasileiro. São Paulo: Fundação Perseu Abramo, p. 177-196, 2015.

CESARINO, Letícia. Identidade e representação no bolsonarismo: corpo digital do rei, bivalência conservadorismo-neoliberalismo e pessoa fractal. Revista de Antropologia, v.62, n.3, p.530-557, 2019.

CHAPOLA, Ricardo. Ato por impeachment de Dilma reúne 2,5 mil em São Paulo. Estadão, 01 nov. 2014. Disponível em: http://politica.estadao.com.br/noticias/geral,ato-por-impeachment-de-dilma-reune-2-5-mil-em-sao-paulo, 1586653. Acesso em: 05 ago. 2020.

CURI, Martin. Espaços da emoção: arquitetura futebolística, torcida e segurança pública. Niterói, 2012. Tese (Doutorado em Antropologia) - Universidade Federal Fluminense, Niterói, 2012.

CURI, Martin et al. Observatório do Torcedor: o Estatuto. CBCE, v.30, n.1, p.25-40, 2008.

DARLINGTON, Shasta. Jair Bolsonaro, Candidate in Brazil, Faces Women's Calls: \#NotHim. The New York Times, 24 set. 2018. 
O ópio do povo? O futebol e as manifestações políticas no Brasil entre 2013 e 2020 Eric Monné Fraga de Oliveira

Disponível em: https://www.nytimes.com/2018/09/24/world/ americas/brazil-election-jair-bolsonaro.html. Acesso em: 16 set. 2020.

DA SILVA, Edilson Márcio Almeida. Das reportagens policiais às coberturas de segurança pública - representações da 'violência urbana' em um jornal do Rio de Janeiro. Tese (Doutorado em Antropologia) - Universidade Federal Fluminense, Niterói, 2007.

DOUGLAS, Mary. Pureza e perigo. Lisboa: 70, 1991.

DUNNING, Eric. Sport matters - sociological studies of sport, violence and civilization. Londres: Routledge, 1999.

ELIAS, Norbert; SCOTSON, John L. Os estabelecidos e os outsiders - sociologia das relações de poder a partir de uma pequena comunidade. Rio de Janeiro: Zahar, 2000.

ESTADO DE MINAS. Avenida Paulista recebe ato em apoio ao candidato Jair Bolsonaro. Estado de Minas, 30 set. 2018. Disponível em: https://www.em.com.br/app/noticia/politica/2018/09/30/ interna_politica,993028/avenida-paulista-recebe-ato-em-apoio-ao-candidato-jair-bolsonaro.shtml. Acesso em: 16 set. 2020.

ESTADO DE MINAS. Grupo de manifestantes faz protesto contra Bolsonaro em frente ao Planalto. Estado de Minas, 20 mai. 2020. Disponível em: https://www.em.com.br/app/noticia/politica/2020/05/20/interna_politica,1149022/grupo-de-manifestantes-faz-protesto-contra-bolsonaro-em-frente-ao-plan.shtml. Acesso em: 17 set. 2020.

FERNANDES, Eduardo Georjão; TEIXEIRA, Alex Niche. Por um modelo analítico no estudo dos enquadramentos midiáticos a processos de mobilização. Sociedade e Estado, Brasília, v. 33, n. 3, p.915-937, 2018.

FLORENZANO, José Paulo. A democracia corinthiana: práticas de libertação no futebol brasileiro. São Paulo, 2003. Tese (Doutorado em Ciências Sociais) - Pontifícia Universidade Católica de São Paulo, São Paulo, 2003. 
FLORENZANO, José Paulo. Um calcio diverso: partidas políticas e torcidas ultras. In: HOLLANDA, Bernardo Borges Buarque de; REIS, Heloísa Helena Baldy dos (Orgs.). Hooliganismo e Copa de 2014. Rio de Janeiro: 7Letras, 2014, p. 77-90.

G1. Na abertura da Copa, protestos pelo país tiveram bombas de gás e detidos. G1, 12 jun. 2014a. Disponível em: http://g1.globo. com/politica/noticia/2014/06/na-abertura-da-copa-confrontospelo-pais-tiveram-bombas-de-gas-e-detidos.html. Acesso em: 16 mar. 2017.

G1. Com mais de 20 protestos, $1^{\text {a }}$ semana de Copa tem 180 detidos em atos. G1, 19 jun. 2014b. Disponível em: ; http://g1.globo. com/politica/noticia/2014/06/com-mais-de-20-protestos-1-semana -de-copa-tem-180-detidos-em-atos.html. Acesso em: 16 mar. 2017.

G1. Protestos contra Bolsonaro ocorrem em 26 estados e DF; atos a favor, em 16. G1, 29 set. 2018a. Disponível em: https://g1.globo. com/politica/noticia/2018/09/29/manifestantes-fazem-atos-a-tarde-contra-e-favor-de-bolsonaro.ghtml. Acesso em: 16 set. 2020.

G1. Manifestantes fazem atos a favor de Bolsonaro em Belo Horizonte, Brasília e outras 18 cidades na manhã deste domingo. G1, 30 set. 2018b. Disponível em: https://g1.globo.com/ politica/noticia/2018/09/30/manifestantes-protestam-a-favor-de-bolsonaro-em-belo-horizonte-brasilia-e-outras-18-cidades-na-manha-deste-domingo.ghtml. Acesso em: 16 set. 2020.

G1. Cidades brasileiras registram panelaço contra Bolsonaro pelo $15^{\circ}$ dia seguido. G1, 31 mar. 2020. Disponível em: https:// g1.globo.com/politica/noticia/2020/03/31/cidades-brasileiras-registram-panelaco-contra-bolsonaro-pelo-15o-dia-seguido.ghtml. Acesso em: 02 set. 2020.

G1 RIO. Protestos pró e contra governo de Jair Bolsonaro começam pacíficos, mas acabam em confusão no Rio. G1, 31 mai. 2020. Disponível em: https://g1.globo.com/rj/rio-de-janeiro/ noticia/2020/05/31/pm-usa-bombas-de-gas-para-dispersar-mani- 
O ópio do povo? O futebol e as manifestações políticas no Brasil entre 2013 e 2020 Eric Monné Fraga de Oliveira

festantes-contra-bolsonaro-em-copacabana.ghtml. Acesso em: 17 set. 2020.

GEERTZ, Clifford. A interpretação das culturas. Rio de Janeiro: Guanabara, 1989.

GLOBOESPORTE.COM. Flamengo abre venda de ingressos para jogo contra o Coritiba nesta sexta. Globo Esporte, 11 nov. 2016. Disponível em: http://globoesporte.globo.com/futebol/times/ flamengo/noticia/2016/11/flamengo-abre-venda-de-ingressos-para-jogo-contra-o-coritiba-nesta-sexta.html. Acesso em: 09 nov. 2017.

GUEDES, Simoni Lahud; DA SILVA, Edilson Márcio Almeida. O segundo sequestro do verde e amarelo: futebol, política e símbolos nacionais. Cuadernos de Aletheia, n. 3, p.73-89, 2019.

HOLLANDA, Bernardo Borges Buarque de; MEDEIROS, Jimmy; TEIXEIRA, Rosana da Câmara. A voz da arquibancada: narrativas de lideranças da Federação de Torcidas Organizadas do Rio de Janeiro (FTORJ). Rio de Janeiro: 7Letras, 2015.

HONNETH, Axel. Luta por reconhecimento - a gramática moral dos conflitos sociais. Rio de Janeiro: 34, 2009.

JÚNIOR, Janir. Protestos no Mané Garrincha: 27 feridos e oito presos na abertura. Globo Esporte, 15 jun. 2013. Disponível em: http://globoesporte.globo.com/futebol/selecao-brasileira/noticia/2013/06/de-novo-manifestantes-protestam-no-mane-garrincha-e-clima-fica-tenso.html. Acesso em: 14 mar. 2017.

LACERDA, Angela et al. Grupos protestam pelo Brasil contra a realização da Copa do Mundo. Estadão, 25 jan. 2014. Disponível em: http://esportes.estadao.com.br/noticias/futebol,grupos-protestam-pelo-brasil-contra-a-realizacao-da-copa-do-mundo,1122884; Acesso em: 16 mar. 2017.

LEAL, Aline. Quase 2 milhões de brasileiros participaram de manifestações em 438 cidades. Agência Brasil, 21 jun. 2013. Disponível em: http://memoria.ebc.com.br/agenciabrasil/ 
noticia/2013-06-21/quase-2-milhoes-de-brasileiros-participaram-de-manifestacoes-em-438-cidades. Acesso em: 14 mar. 2017.

LEIFERT, TIAGO. Evento esportivo não é lugar de manifestação política. GQ, 26 fev. 2018. Disponível em: https://gq.globo.com/ Colunas/Tiago-Leifert/noticia/2018/02/evento-esportivo-nao-e-lugar-de-manifestacao-politica.html. Acesso em: 31 jul. 2020.

MAGALHÃES, Mário. Rio, São Paulo e BH lideram ranking de cidades com mais protestos na Copa. UOL, 09 jul. 2014. Disponível em: http://blogdomariomagalhaes.blogosfera.uol.com. br/2014/07/09/rio-sao-paulo-e-bh-lideram-ranking-de-cidadescom-mais-protestos-na-copa. Acesso em: 16 mar. 2017.

MAGRI, Diogo. Torcidas antifascistas se multiplicam nas arquibancadas do futebol brasileiro. El País, 25 dez. 2019. Disponível em: https://brasil.elpais.com/esportes/2019-12-25/torcidas-antifascistas-se-multiplicam-nas-arquibancadas-do-futebol-brasileiro.html. Acesso em: 19 ago. 2020.

MALAIA, João M. C. Torcer, torcedores, torcedoras, torcidas (bras.): 1910-1950. In HOLLANDA, Bernardo Borges Buarque de. (et al.). A torcida brasileira. Rio de Janeiro: 7 Letras, 2012, p.53-85.

MARIN, Pedro. 'Breque dos apps': a greve de entregadores e o direito à saúde. Revista Opera, 30 jun. 2020. Disponível em: https://revistaopera.com.br/2020/06/30/breque-dos-apps-agreve-de-entregadores-e-o-direito-a-saude/. Acesso em: 17 set. 2020.

MARTINS, Mariana Zuaneti; REIS, Heloisa Helena Baldy dos. Cidadania e direitos dos jogadores de futebol na Democracia Corinthiana. Revista Brasileira de Educação Física e Esporte, São Paulo, v. 28, n. 3, p.429-440, 2014.

MARX, Karl. Crítica da filosofia do direito de Hegel. São Paulo: Boitempo Editorial, 2005. 
MÁXIMO, João. Memórias do futebol brasileiro. Estudos

Avançados, São Paulo, v. 13, n. 37, p. 179-188, 1999.

MEDEIROS, Étore. Dilma e Lula elevaram os investimentos em educação? A Pública, 13 jul. 2016. Disponível em: https://apublica.org/2016/07/truco-dilma-e-lula-elevaram-os-investimentos-em-educacao/. Acesso em: 25 ago. 2020.

MELO, Victor Andrade de. Sportsmen: os primeiros momentos da configuração de um público esportivo n Brasil. In HOLLANDA, Bernardo Borges Buarque de. (et al.). A torcida brasileira. Rio de Janeiro: 7 Letras, 2012, p.21-52.

MELUCCl, Alberto. "The process of collective identity". Social Movements and Culture, v. 4, pp. 41-63, 1995.

MORA, Marcelo. Sem-teto fazem protesto contra a Copa na Zona Leste de São Paulo. G1, 04 jun. 2014. Disponível em: http://g1.globo.com/sao-paulo/noticia/2014/06/sem-teto-fazem-protesto-contra-copa-na-zona-leste-de-sao-paulo.html. Acesso em: 16 mar. 2017.

\section{5}

MOREIRA, Ricardo et al. Protesto contra a Copa termina em confronto com a polícia no DF. G1, 27 mai. 2014. Disponível em: http://g1.globo.com/distrito-federal/noticia/2014/05/protesto-contra-copa-termina-em-confronto-com-policia-no-df.html. Acesso em: 16 mar. 2017.

NICÁCIO, Luiz Gustavo et al. Campeonato Brasileiro de 2007: a relação do torcedor de futebol com o Estatuto de Defesa do torcedor na cidade de Belo Horizonte (MG). CBCE, v.30, n. 2, p.25-38, 2009.

OLIVEIRA, Eric Monné Fraga de. A paixão como confronto: disputas discursivas sobre o ato de torcer. Rio de Janeiro, 2018. Tese (Doutorado em Sociologia) - Instituto de Estudos Sociais e Políticos da Universidade do Estado do Rio de Janeiro, Rio de Janeiro, 2018. 
OLIVEIRA, Marcelo. Maiores eventos pró e contra Bolsonaro ocorrerão em cidades diferentes. UOL, 21 mar. 2020. Disponível em: https://noticias.uol.com.br/politica/ultimas-noticias/2020/06/21/ maiores-eventos-pro-e-contra-bolsonaro-ocorrerao-em-cidades-diferentes.htm. Acesso em: 17 set. 2020.

OPINIÃO PÚBLICA. Reprovação a Bolsonaro alcança 43\%, e aprovação fica estável. Folha de São Paulo, 28 mai. 2020. Disponível em: http://datafolha.folha.uol.com.br/opiniaopublica/2020/05/ 1988731-reprovacao-a-bolsonaro-sobe-atinge-43-aprovacao-fica-estavel.shtml. Acesso em: 25 ago. 2020.

PALHANO, Gabriela de. Sete capitais têm protestos contra o aumento das passagens de ônibus. G1, 14 jun. 2013. Disponível: http://g1.globo.com/jornal-hoje/noticia/2013/06/sete-capitais-tem-protestos-contra-o-aumento-das-passagens-de-onibus.html. Acesso em: 14 mar. 2017.

PASSARINHO, Nathalia. 'Futebol e política não se misturam', diz Mercadante sobre vaias a Dilma. G1, 17 jun. 2013. Disponível em: http://g1.globo.com/politica/noticia/2013/06/futebol-e-politica-nao-se-misturam-diz-mercadante-sobre-vaias-dilma.html. Acesso em: 14 mar. 2017.

PETROCILO, Carlos; SABINO, Alex. Com conflitos internos, torcidas planejam novo ato pró-democracia. Folha de São Paulo, 01 jun. 2020. Disponível em: https://www1.folha.uol.com.br/esporte/2020/06/com-conflitos-internos-torcidas-planejam-novo-ato-pro-democracia.shtml. Acesso em: 03 jun. 2020.

\section{PEW RESEARCH CENTER BRAZIL REPORT. Brazilian discontent} ahead of World Cup - President Rousseff gets poor marks on key issues. 2014. Disponível em: http://www.pewglobal. org/files/2014/06/Pew-Research-Center-Brazil-Report-FINALJune-3-2014.pdf. Acesso em: 15 ago. 2015.

PINTO, António Costa. De regresso ao fascismo. Análise Social, Lisboa, n. 179, p. 611-627, 2006. 
PUFF, Jefferson; KAWAGUTI, Luís. Polícia usa violência em protesto e fere ao menos 10 jornalistas no Rio. BBC, 14 jul. 2014. Disponível em: http://www.bbc.com/portuguese/noticias/2014/07/140713_wc2014_protesto_feridos_lk_lgb. Acesso em: 16 mar. 2017.

REDE BRASIL ATUAL. Atos e paralisações marcam Dia Nacional de Luta e Luto contra Bolsonaro. Rede Brasil Atual, 07 ago. 2020. Disponível em: https://www.redebrasilatual.com.br/politica/2020/08/dia-de-luta-luto-contra-bolsonaro/. Acesso em: 17 set. 2020.

REIS, Heloisa Helena Baldy dos; LOPES, Felipe Tavares Paes; MARTINS, Mariana Zuaneti. Políticas públicas voltadas para atletas e torcedores de futebol: argumentos para dissidentes. Motrivivência v. 26, n. 42, p. 115-130, 2014.

ROCHA, Camila. "Imposto é Roubo!" A formação de um contrapúblico ultraliberal e os protestos pró- impeachment de Dilma Rousseff. Dados, Rio de Janeiro, v. 62, n. 3, e20190076, 2019.

SACCHITIELLO, Bárbara. SBT coloca no ar campanha nacionalista. Meio e Mensagem, 06 nov. 2018. Disponível em: https://www. meioemensagem.com.br/home/midia/2018/11/06/em-campanha-nacionalista-sbt-usa-slogan-ame-o-ou-deixe-o.html. Acesso em: 03 set. 2020.

SANTOS, Wanderley Guilherme dos. A democracia impedida: o Brasil no século XXI. Rio de Janeiro: FGV, 2017.

SILVA, Silvio Ricardo da. et al. Observatório do torcedor: a relação dos torcedores de futebol e torcedores de voleibol com o Estatuto de Defesa do Torcedor em Belo Horizonte. In: XV Congresso Brasileiro de Ciências do Esporte / II Congresso Internacional de Ciências do Esporte, 2007, RECIFE. XV CONBRACE / II CONICE, 2007.

SINGER, André. Brasil, junho de 2013: classes e ideologias cruzadas. Novos Estudos - Dossiê: Mobilizações, Protestos e Revoluções, n.97, p.23-40, nov. 2003. 
SINGER, André; LOUREIRO, Isabel Maria. (orgs.). As contradições do lulismo. A que ponto chegamos?. São Paulo: Boitempo, 2016.

SÓCRATES; GOZZI, Ricardo. Democracia corintiana: a utopia em jogo. São Paulo: Boitempo; 2002.

SOUZA, Denaldo Alchorne de. As origens de ‘O futebol é o ópio do povo'. ARQUIBANCADA, v. 108, p. 31, 2018.

SOUZA, Denaldo Alchorne de. Pra frente Brasil: identidade nacional e futebol: enquadramentos, resistências e esquecimentos (1950-1983). São Paulo, 2011. Tese (Doutorado em História) Pontifícia Universidade Católica de São Paulo, São Paulo, 2011.

SPAAIJ, Ramón. Understanding football hooliganism - a comparison of six western European football clubs. Amsterdam: Amsterdam University Press, 2006.

STOCHERO, Tahiane; PASSARINHO, Nathalia. Há um ano, 'batalha da Consolação' impulsionou protestos pelo país. G1, 13 jun. 2014. Disponível em: http://g1.globo.com/politica/noticia/2014/06/ha-um-ano-batalha-da-consolacao-impulsionou-protestos-pelo-pais. html. Acesso em: 14 mar. 2017.

TATAGIBA, Luciana; GALVAO, Andreia. Os protestos no Brasil em tempos de crise (2011-2016). Opinião Publica, Campinas, v. 25, n. 1, p. 63-96, 2019.

TEIXEIRA, Leonardo Antonio de Carvalho. Congregar, congraçar e unir: a atuação da Associação das Torcidas Organizadas do Rio de Janeiro (1981-1989). Rio de Janeiro, 2014. Dissertação (Mestrado em História Social) - Universidade do Estado do Rio de Janeiro, Rio de Janeiro, 2014.

TOLEDO, Luiz Henrique de. Políticas da corporalidade: socialidade torcedora entre 1990-2010. In: HOLLANDA, Bernardo Borges Buarque de. (et al.) A Torcida Brasileira. Rio de Janeiro: 7 Letras, 2012, p.122-158. 
O ópio do povo? O futebol e as manifestações políticas no Brasil entre 2013 e 2020 Eric Monné Fraga de Oliveira

TOLEDO, José Roberto de. Um protesto histórico, menos na tevê. Piauí, 29 set. 2018. Disponível em: https://piaui.folha.uol.com.br/ um-protesto-historico-menos-na-teve. Acesso em: 16 set. 2020.

TRAVERSO, Enzo. Do Fascismo ao Pós-Fascismo. Revista de Estudos e Pesquisas sobre as Américas, v. 13, n. 2, p. 12-44, 2019.

UNIVERSA. Protesto contra Bolsonaro: vídeo mostra atos no Brasil e no mundo. UOL, 29 set. 2018. Disponível em: https:// www.uol.com.br/universa/noticias/redacao/2018/09/29/protesto-contra-bolsonaro-video-mostra-atos-no-brasil-e-no-mundo.htm. Acesso em: 16 set. 2020.

UOL. Manifestantes protestam contra Bolsonaro na Esplanada dos Ministérios. UOL, 26 jul. 2020. Disponível em: https://noticias. uol.com.br/politica/ultimas-noticias/2020/07/26/manifestantes-protestam-contra-bolsonaro-na-esplanada-dos-ministerios.htm. Acesso em: 17 set. 2020.

URIBE, Gustavo; LIMA, Daniela; LIMA, Galeano. Manifestação contra Dilma reúne 2.500 pessoas em São Paulo. Folha de São Paulo, 01 nov. 2014. Disponível em: http://www1.folha.uol.com. br/poder/2014/11/1542047-ato-em-sao-paulo-pede-impeachment-de-dilma-e-intervencao-militar.shtml. Acesso em: 05 ago. 2020.

WILKSON, Adriano. Haddad recebe apoio de 69 organizadas e entra em poropopó contra Bolsonaro. UOL, 22 out. 2018. Disponível em: https://www.uol.com.br/esporte/futebol/ultimas-noticias/2018/10/22/torcidas-organizadas-apoiam-haddad-contra-bolsonaro.htm. Acesso em: 25 ago. 2020. 